\title{
Study on ethnobotany, phytochemistry, toxicity, and effectiveness of herbal remedies against Boophilus decoloratus in Suba, Kenya
}

\author{
ALFRED OJWANG ONYANGO ${ }^{1}$, JOHN O. KOKWARO ${ }^{1, \vartheta}$, DANIEL W. ONYANGO ${ }^{2}$, AMIR O. YUSUF ${ }^{3}$ \\ ${ }^{1}$ School of Biological Sciences, University of Nairobi. Chiromo Campus, P.O. Box 30197-00100, Nairobi, Kenya. ^email: john.kokwaro@uonbi.ac.ke \\ ${ }^{2}$ Department of Veterinary Anatomy and Physiology, University of Nairobi. Chiromo Campus, P.O. Box 30197-00100, Nairobi, Kenya \\ ${ }^{3}$ Department of Chemistry, University of Nairobi. Chiromo Campus, P.O. Box 30197-00100, Nairobi, Kenya
}

Manuscript received: 24 January 2019. Revision accepted: 21 May 2019.

\begin{abstract}
Onyango AO, Kokwaro JO, Onyango DW, Yusuf AO. 2019. Study on ethnobotany, phytochemistry, toxicity and effectiveness of herbal remedies against Boophilus decoloratus in Suba, Kenya. Asian J Ethnobiol 2: 38-50. Plants have been found to have a variety of biological activities against insect pests, some of which have been confirmed. The ethnobotany, phytochemistry, toxicity, and acaricidal behavior of crude extracts of three selected plants against blue-tick in Suba Sub-County, Kenya, were investigated as part of this study. In Suba Sub-County, a total of 32 herbalists, ranging in age from 28 to 87, were interviewed using a questionnaire about their knowledge of acaricidal plants. The area's name, a component used, conventional planning, and administration methods were all recorded. The number of medicinal plant citations was highly correlated with the informants' age. Based on independent researches (IR), the study described 16 plants distributed among 13 families. For phytochemical tests, Phytolacca dodecandra, Cissus quadrangularis, and Ipomoea kituiensis were collected and extracted in methanol, dichloromethane $(1: 1 \mathrm{v} / \mathrm{v})$, and distilled water separately. Terpenoids, tannins, saponins, flavonoids, and alkaloids were all present in the three plants, except flavonoids, which were absent in P. dodecandra.To test the efficacy of crude extracts of these selected plants, larvae of the Boophilus spp., the tick was used in an in vitro acaricidal activity analysis. The effects of $2.5,5$, and $10 \mathrm{mg} / \mathrm{mL}$ concentrations of water and methanol in DCM (1:1 v/v) crude extracts of $P$. dodecandra (leaves), $C$. quadrangularis (whole), and I. kituiensis (leaves) were compared to that produced by the standard reference acaricide, almatix ${ }^{\circledR}(12.5$ percent amitraz) as a positive control. The extracts' activity against larvae was tested, and the extracts were most active at $10 \mathrm{mg} / \mathrm{mL}$ concentration. The death rate was determined within 24 hours. The extracts of Cissus quadrangularis (100 kills at $10 \mathrm{mg} / \mathrm{mL})$ and $P$. dodecandra (100 kills at 5 and $10 \mathrm{mg} / \mathrm{mL}$ ) was the most potent compared to almatix, while I. kituiensis methanol/DCM $(1: 1 \mathrm{v} / \mathrm{v})$ extract was the least potent. The variance analysis revealed significant differences in the acaricidal activity of plant extracts at all concentrations tested $(2.5,5$, and $10 \mathrm{mg} / \mathrm{mL})(\mathrm{P} \leq 0.05)$. The LC50 of Boophilus decoloratus larvae was determined if methanol: DCM (1:1 v/v) extracts of I. kituiensis showed mild toxicity, whereas those of $P$. dodecandra and $C$. quadrangularis showed high toxicity. This study concluded that $C$. quadrangularis (whole), I. kituiensis (leaves), and $P$. dodecandra (leaves) extracts are acaricidal and as potent at high concentrations as almatix. The mortality of the larvae increases with increasing extract concentration, indicating that the extracts of the top three study plants are effective in blue-tick control. It is recommended that isolate and purify crude compounds, and bioassay of these isolated compounds be performed on the same blue-tick larvae to achieve highly efficacious conventional acaricides.
\end{abstract}

Keywords: Amitraz, Boophilus decoloratus, acaricidal activity, medicinal plants

\section{INTRODUCTION}

Disease transmission by external and internal parasites is one of the major constraints to livestock production and improvement in the tropics and subtropics (Belay et al., 2013). Pathogens such as bacteria, spirochetes, protozoa, viruses, and toxins are transmitted by external parasites (Rajput et al., 2006). Ticks are the most common external parasites in livestock, and their feeding and disease transmission cause significant financial losses to livestock owners (Jongejan and Uilenberg 2004).

There are many methods for controlling ticks and tickborne diseases, but the most successful tick control approach to date is site-specific and repeated acaricide applications (Di Giulio et al., 2009). However, their use is linked to several issues, including multi-chemical resistance in pest species, application costs, poisoning of treated animals and humans, residues in meat and milk, and environmental pollution, especially in water bodies (Rajput et al. 2006). Secondary metabolites are phytochemicals found in plants that are not explicitly used by the plant but can be used as protective mechanisms against herbivorous species such as insects. Since phytochemicals have a wide range of actions, pests are less likely to develop resistance than synthetic pesticides. Ethnoveterinary acaricides are a low-cost, familiar-to-locals, locally available, and easily accessible alternative to synthetic acaricides for resourcestrapped farmers (Salwa 2010). These bio-pesticides are available in various forms, including crude conditions and pure active compounds. On the other hand, scientific testing is needed to prove their safety and efficacy (Green et al. 1996).

Since they are environmentally friendly, bioactive plant extracts are gaining popularity worldwide (Sanjay and Tiku 2009). Saponins, tannins, flavonoids, terpenoids, and alkaloids are the most common insecticidal compounds found in plant extracts. They serve as antifeedants, 
sterilants, repellents, and poisons that cause paralysis in many herbivores, including insects (Isman 2006).

Due to its proximity to Ruma National Park, which contains tick hosts such as buffalos, and the region's remoteness in veterinary facilities, such as cattle dips, tick prevalence in Suba Sub-County is high. To assess the ethnobotanical, phytochemical, toxicity, and acaricidal activity of anti-tick and, in particular, anti-blue tick, i.e., herbal remedies for cattle, this study was conducted on ethnoveterinary medicinal plants used by herbalists in Suba Sub-County, Kenya.

The goals of this study were (i) to identify and document the first three major plant species commonly used in traditional tick control in Suba Sub-County (by interviewing traditional herbalists). (ii) Using water and methanol in dichloromethane $(1: 1 \mathrm{v} / \mathrm{v})$ to extract the three plant materials Cissus quadrangularis (whole), Phytolacca dodecandra (leaves), and Ipomoea kituiensis (leaves). (iii) To test the effectiveness of the anti-tick plants on $B$. decoloratus larvae (iv) Using a brine shrimp (Artemia salina) lethality assay to assess the toxicity of crude plant extracts. (iv) To identify the phytochemicals found in the anti-tick plant species of choice.

\section{MATERIALS AND METHODS}

\section{The study area}

Adult ticks of the Boophilus decoloratus species were collected in Kenya's Suba Sub-County of Homa Bay County, which is located between latitudes $0^{\circ} 30^{\prime} \mathrm{S}$ and $0^{\circ} 50^{\prime} \mathrm{S}$ and longitudes $34^{\circ} 0^{\prime} \mathrm{E}$ and $34^{\circ} 20^{\prime} \mathrm{E}$. (Figure 1 ). The average elevation of the region is 1000 meters above sea level, with annual rainfall varying from 250 to 700 millimeters. Temperatures range from a mean minimum of $17.1^{\circ} \mathrm{C}$ to a mean maximum of $34.8^{\circ} \mathrm{C}$ annually.

According to the National Boundary Commission, Suba Sub-County is divided into nine sections: Gwassi West, Gwassi East, Gwassi South, Gwassi Central, Kaksingri West, andGwassi North, Kaksingri East, Kaksingri Central, and Ruma. To the north, it is bordered by Lake Victoria.

Suba Sub-County has a population of approximately 103,789 people, with 34 percent living in urban areas, according to the 2009 census (GoK 2009; 2012). Although the Luo ethnic group is the most populous, other ethnic groups like the Luhyia and Kisii also live in the region.

The region's main economic activities are subsistence agriculture, livestock breeding, and trade. In certain places, the vegetation is savannah-like, with shrubs and sparse trees. The study location, Suba Sub-County, was chosen because it represents a primarily free-range smallholder cattle production system and is close to Ruma National Park. The presence of wild hosts such as buffaloes and rhinos increased the risk of tick occurrence.

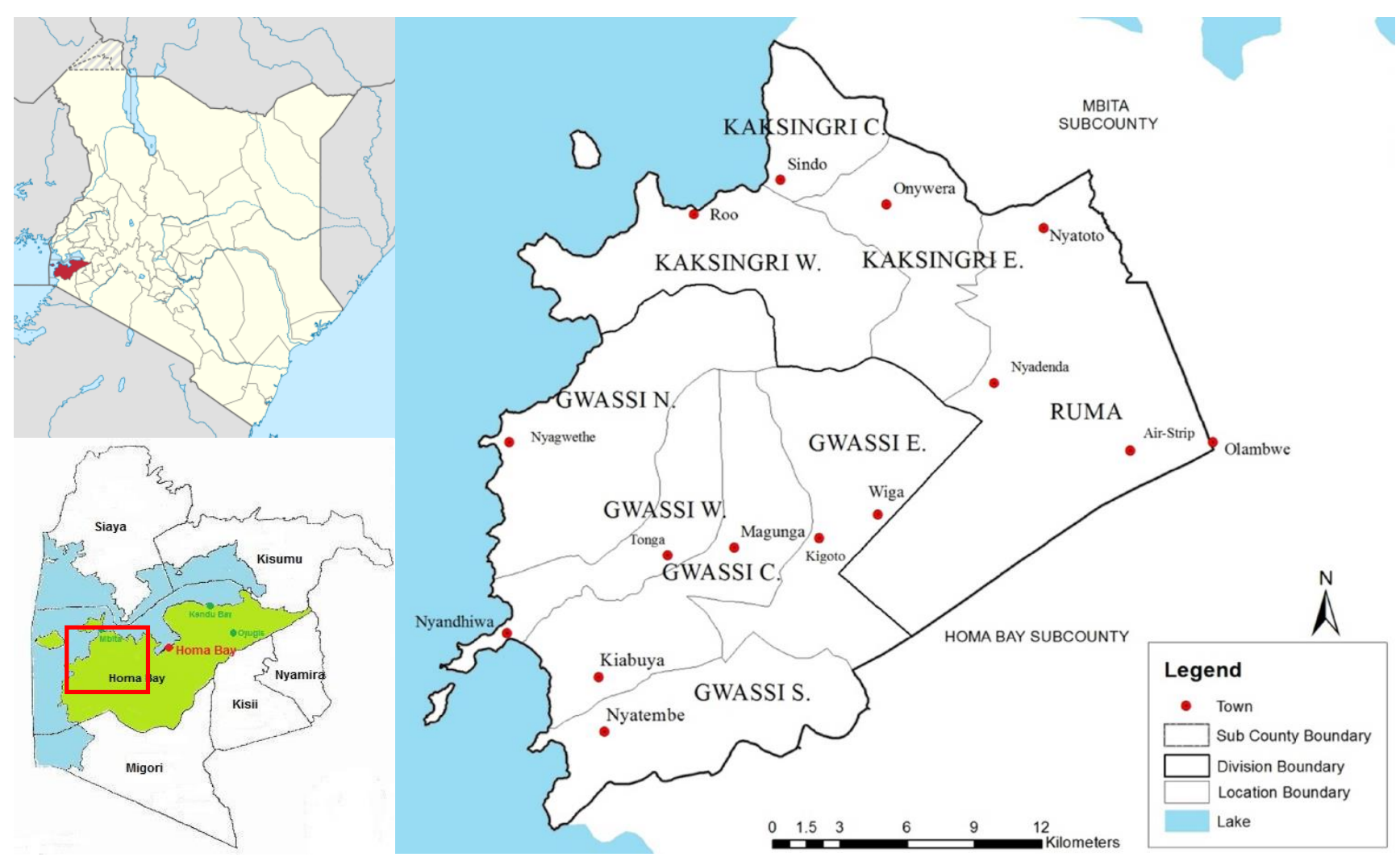

Figure 1. The map of Kenya showing Homa Bay County and Suba Sub-County 


\section{Identification of ethnoveterinary practitioners and collection of ethnobotanical data}

The study site was divided into twenty strata based on their recent administrative sub-locations. A field survey was conducted with the assistance of local administration (chiefs, assistant chiefs, village elders, and the general public) to identify traditional medical practitioners and medicinal plant vendors with background information on plants that would be useful in this research. Four sublocations, representing four villages, were purposefully chosen from among the twenty-four sub-locations because these communities rely heavily on traditional healing and have inherited many skills from their forefathers. According to Orozcoz and Lent (2005), purposive sampling obtained ethnoveterinary data from informants. This is a strategy for the sample that is not based on probability. The information was gathered from 32 people in four villages in the study area: Kiembe village in Gwassi West, Kisaku village in Gwassi North, Nyadenda village in Kaksingri Central, and Roo village in Kaksingri West. A 23-questions for the questionnaire were created and used to gather information from resource persons. Mr. Opella, the Chief of Gwassi West Place, referred me to a Kiembe village elder, who assisted me in identifying five herbalists with whom I pre-tested my questionnaire during the pre-survey. Their respective elders reported the remaining 27 informants in the remaining three villages. The questionnaire looks for local names for acaricidal species and methods of acaricide preparation, plant habits, and plant parts used in acaricide preparation. Anti-tick herbalists offered specific and high-quality details.

Plant specimens were collected in pairs; one was used for preliminary identification in the field as mentioned previously (Beentje 1994; Agnew 2013), while the other was pressed and transported to the University of Nairobi herbarium (NAI) for authentication and comparison with the permanent prepared herbarium collections.

\section{Selection of priority plants}

Priority plants were chosen based on a survey conducted in Suba Sub-County between December 2014 and January 2015. The respondents prepared a frequency report on plants that are acaricidal agents. According to the frequencies in the independent information for each plant, the information was organized in order of ranks, from highest (rank 1) to lowest (rank 16).

Three of the most common plants, Phytolacca dodecandra (leaves), Cissus quadrangularis (whole), and Ipomoea kituiensis (leaves), were chosen and the sections used as medicine were collected and subjected to chemical and bioassay tests. Herbalists described the details on the valuable areas of the plants - collection and drying of plant parts.

\section{Phytolacca dodecandra and Ipomoea kituiensis}

The leaves of the two plants were plucked and stuffed into a polythene bag, then put in a cooler box and shipped to Nairobi. After 14 days of drying in the shade, the products were ground into a fine powder using an electric mill. The dry powders of P.dodecandra and I.kituiensis were $354.7 \mathrm{~g}$ and $392.8 \mathrm{~g}$, respectively.

\section{Cissus quadrangularis}

The entire plant was uprooted, the roots were washed first, and the whole plant was cut into pieces with an electric blender before being packed into a polythene bag and shipped to Nairobi in a cooler package. After 14 days of shade drying, the material was ground into a fine powder using an electric mill. The total weight of the dry powder was $401.9 \mathrm{~g}$. extraction of plant crude extracts

In 5-litre covered buckets, air-dried ground material (160 grams) was collected separately in 2 liters distilled water, 2 liters dichloromethane (DCM), and 2 liters methanol in a $1: 1(\mathrm{v} / \mathrm{v})$ ratio for 72 hours, then filtered using Whatman's filter paper No. 1 to obtain solvent extracts. The organic extract was dried at room temperature $\left(26-28^{\circ} \mathrm{C}\right)$ using a rotary evaporator in a vacuum at $60^{\circ} \mathrm{C}$. The aqueous extract was deep-frozen and then freeze-dried to obtain a powdered crude extract, which was then put in separate vials and stored at $4^{\circ} \mathrm{C}$ (Sirama et al. 2015). The percentage yield was determined as a ratio of the weight of the extract to the weight of the plant material $(160 \mathrm{~g})$. The weights of the organic and aqueous extracts of the plant were $14.19 \mathrm{~g}$ and $16.38 \mathrm{~g}$, respectively.

\section{Dosage preparation of $2.5,5$, and $10 \mathrm{mg} / \mathrm{mL}$ of the crude extracts and $0.0045 \%$ almatix \\ Preparation of $10 \mathrm{mg} / \mathrm{mL}$}

Weigh $10 \mathrm{~g}$ of ground crude extract and place in a 1liter volumetric flask. Make to volume with $990 \mathrm{~mL}$ deionized water.

\section{Preparation of $5 \mathrm{mg} / \mathrm{mL}$}

Take $50 \mathrm{~mL}$ of $10 \mathrm{mg} / \mathrm{mL}$ in a $100-\mathrm{mL}$ volumetric flask. Make to volume with $50 \mathrm{~mL}$ deionized water.

\section{Preparation of $2.5 \mathrm{mg} / \mathrm{mL}$}

Take $50 \mathrm{~mL}$ of $5 \mathrm{mg} / \mathrm{mL}$ in a $100-\mathrm{mL}$ volumetric flask. Make to volume with $50 \mathrm{~mL}$ deionized water.

\section{Preparation of $0.0045 \%$ almatix}

Take $0.36 \mathrm{~mL}$ of almatix ${ }^{\circledR}(12.5 \%$ amitraz, almatix density $1 \mathrm{~g} / \mathrm{mL}$ ) and place it in a 1-Litre volumetric flask. Add $999.64 \mathrm{~mL}$ of deionized water and stir.

\section{Tick collection, identification, egg incubation, and determination of the $\mathrm{LC}_{50}$}

Ten adult engorged female ticks were collected from cattle in Kenya's Suba Sub-County. The tick and sex authentication was performed at The International Livestock Research Institute's (ILRI) tick veterinary laboratory and verified as adult B.decoloratus. Eggs of blue tick reared at the institution were weighed into $1 \mathrm{~g}$ samples, inserted into test tubes, and incubated for 28 days at a temperature range of $282^{\circ} \mathrm{C}$ and relative humidity of 80 $90 \%$ for egg hatching using the Ducornez et al. (2005) technique with some minor modifications. One hundred (100) larvae that had been acclimatized for 8 days were exposed to crude extracts at concentrations of $2.5,5$, and 
$10 \mathrm{mg} / \mathrm{mL}$ for three minutes using the larval packet immersion process. Control ticks were prepared the same way as to test specimens, with $0.0045 \%$ of $12.5 \%$ amitraz (active ingredient) used as a positive control and $1 \%$ DMSO and water used as negative controls (Walker et al. 2002; Ducornez et al. 2005). Six replicates were used in the experiments. The percentage mortality of B.decoloratus larvae was measured as a function of crude plant extract concentrations $(2.5,5$, and $10 \mathrm{mg} / \mathrm{mL})$ over a 24-hour treatment period. The LC50 was determined (concentration killing 50 percent of the ticks). After 24 hours, the average mortalities of B.decoloratus tick larvae were measured as a function of crude plant extract concentrations, with the corresponding LC50 determined for each plant species. Bioassay data subjected to a probit analysis program (Finney 1971) revealed that the LC50 of crude plant extracts was based on the method of extraction.

\section{Determination of acute toxicity of crude extracts on brine shrimp}

Meyer's approach was used to conduct the acute toxicity assay on phototropic brine shrimp nauplii (brine shrimp larvae) (Musila et al., 2013). 38 grams of sea salt is dissolved in 1 liter of distilled water to make artificial seawater. A $14 \mathrm{~cm}$ by $9 \mathrm{~cm}$ by $5 \mathrm{~cm}$ tank with two unequal chambers and several holes on the divider was used for hatching. The chambers were packed with artificial seawater. To provide food for the nauplii, brine shrimp eggs were put in the larger chamber, and yeast was added. The larger chamber was then covered in the dark background paper, while the smaller chamber was lit. The incubation period was 48 hours at a temperature range of $23-29^{\circ} \mathrm{C}$ to allow hatching, and nauplii were collected in the illuminated chamber. Toxicological research on brine shrimp may be extrapolated to other species.

In order to measure toxicity, different concentrations of the crude extract in seawater were used, namely 10, 100, and $1000 \mathrm{~g} / \mathrm{mL}$ (see Table 1). A stock solution of 10,000 $\mathrm{g} / \mathrm{mL}$ was prepared for each crude extract. The aqueous extract's stock solution of $10,000 \mathrm{~g} / \mathrm{mL}$ was prepared by dissolving $0.1 \mathrm{~g}$ of the crude extract in distilled water and then making it to volume in a $10-\mathrm{mL}$ volumetric flask with the same distilled water. To make the stock solution for the organic extract, $0.1 \mathrm{~g}$ of sample was first dissolved in $1 \%$
DMSO and then diluted with distilled water to $10 \mathrm{~mL}$ in a volumetric flask.

Using Pasteur pipettes, ten brine shrimp larvae were removed from the hatching tank and put in $4.5 \mathrm{~mL}$ of seawater, followed by $0.5 \mathrm{~mL}$ of stock solution $(10,000$ $\mathrm{g} / \mathrm{mL}$ ), resulting in a concentration of $1000 \mathrm{~g} / \mathrm{mL} .4 .95 \mathrm{~mL}$ of seawater and $0.05 \mathrm{~mL}$ of stock solution were used to make a concentration of $100 \mathrm{~g} / \mathrm{mL} .4 .995 \mathrm{~mL}$ seawater and a $0.005 \mathrm{~mL}$ stock solution were combined to concentrate 10 $\mathrm{g} / \mathrm{mL}$ (Table 1). Control experiments were conducted using artificial seawater and DMSO for organic extract, and for aqueous extract, only artificial seawater was used (Odhiambo et al., 2014). Three replicates were performed for the three serial dilutions of different crude extracts and the power. Surviving nauplii were counted using a magnifying glass after 24 hours, and the average mortality at each concentration was calculated because it is needed for calculating the LC50.

\section{Phytochemical screening}

The organic and water extracts of the three selected botanicals were phytochemically analyzed using standard methods defined in Jigna and Sumitra (2007) and Mariita et al. (2011). The extracts were screened for phytochemicals (saponins, alkaloids, flavonoids, tannins, and terpenoids) as follows: Saponins (Foam test)

For 10 minutes, a powdered sample of plant extract (1 $\mathrm{mg}$ ) was applied to $10 \mathrm{~mL}$ of distilled water in a hot water bath. The hot mixture was filtered and allowed to cool. 2.5 $\mathrm{mL}$ filtrate was diluted to $10 \mathrm{ml}$ with distilled water and vigorously shaken for 2 minutes. The presence of saponins in the filtrate was suggested by a stable 15-minute frothing (Jigna and Sumitra 2007; Mariita et al. 2011). The process was repeated for each crude extract.

\section{Alkaloids (Dragendorff's test)}

The dry crude plant extract $(0.2 \mathrm{~g})$ was boiled in $5 \mathrm{ml}$ of $2 \%$ hydrochloric acid for 2 minutes and then cooled. It was then filtered, and three drops of Dragendorff's reagent were added to one milliliter of filtrate. The presence of alkaloids was suggested by a red precipitate (Jigna and Sumitra 2007; Mariita et al. 2011). The process was repeated for each crude extract.

Table 1. Brine shrimp bioassay set up for each plant extract

\begin{tabular}{|c|c|c|c|c|c|}
\hline $\begin{array}{c}\text { Volume of Artificial } \\
\text { seawater }(\mathbf{m l})\end{array}$ & $\begin{array}{c}\text { No of Brine shrimp } \\
\text { larvae }\end{array}$ & $\begin{array}{c}\text { Volume of stock } \\
\text { solution }(\mathrm{ml}) \\
\end{array}$ & $\begin{array}{c}\text { Concentration } \\
(\mu \mathrm{g} / \mathrm{ml})\end{array}$ & $\begin{array}{l}\text { Nature of } \\
\text { experiment }\end{array}$ & $\begin{array}{c}\text { Final volume in the } \\
\text { vial }(\mathrm{ml})\end{array}$ \\
\hline 4.5 & 10 & 0.5 & 1,000 & Trial & 5 \\
\hline 4.5 & 10 & 0.5 & 1,000 & Repeat & 5 \\
\hline 4.5 & 10 & 0.5 & 1,000 & Repeat & 5 \\
\hline 4.95 & 10 & 0.05 & 100 & Trial & 5 \\
\hline 4.95 & 10 & 0.05 & 100 & Repeat & 5 \\
\hline 4.95 & 10 & 0.05 & 100 & Repeat & 5 \\
\hline 4.995 & 10 & 0.005 & 10 & Trial & 5 \\
\hline 4.995 & 10 & 0.005 & 10 & Repeat & 5 \\
\hline 4.995 & 10 & 0.005 & 10 & Repeat & 5 \\
\hline 5 & 10 & 0 & 0 & Control & 5 \\
\hline 5 & 10 & 0 & 0 & Control & 5 \\
\hline 5 & 10 & 0 & 0 & Control & 5 \\
\hline
\end{tabular}




\section{Tannins (Ferric chloride test)}

A powdered plant extract sample $(0.5 \mathrm{mg})$ was boiled for 5 minutes in $10 \mathrm{~mL}$ distilled water, cooled, and filtered in a test tube. The presence of tannins was identified by adding 5 drops of $0.1 \%$ ferric chloride to the filtrate and looking for brownish green or blue-black coloration (Jigna and Sumitra 2007; Mariita et al. 2011). Both of the crude extracts were subjected to the same treatment.

\section{Flavonoids (Alkaline reagent test)}

One g powdered plant extract was boiled for 5 minutes with $10 \mathrm{~mL}$ distilled water and filtered while still wet. The yellow color was obtained by adding 5 drops of a $20 \%$ sodium hydroxide solution to $1 \mathrm{ml}$ of the cooled filtrate. As 5 drops of dilute hydrochloric acid are added to colorless, the color changes to yellow, indicating the presence of flavonoids (Jigna and Sumitra 2007; Mariita et al. 2011). Both of the crude extracts were subjected to the same treatment.

\section{Terpenoids (Salkowski test)}

Two $\mathrm{mL}$ chloroform was blended with $1 \mathrm{~g}$ powdered plant extract. To form a layer, $3 \mathrm{~mL}$ of concentrated sulphuric acid was applied. A reddish-brown precipitate coloration suggested the presence of terpenoids at the interface (Jigna and Sumitra 2007; Mariita et al. 2011). Both of the crude extracts were subjected to the same treatment.

\section{Data analysis}

The data were analyzed using descriptive statistics, and the MS Excel® 2010 spreadsheet program was used to perform basic calculations, assess proportions of plant families, habits, preparation methods, and create graphs. The mean, standard errors, and standard deviations of various mortalities observed after treating Boophilus larvae with the various extracts from the three plants at different concentrations were computed using the ANOVA program in the SPSS computer program. The data from each plant extract was then put through a one-way ANOVA to see any significant variations between the different concentrations used. Once the variations between the treatments and the positive controls were known, a Dunnett t-test was used to equate the treatments to the positive controls. The Finney computer software for brine shrimp and acaricidal activities was used to assess the lethal concentration (LC50) of the selected plants at a 95\% confidence interval (Finney 1971).

\section{RESULTS AND DISCUSSION}

\section{Ethnobotany of the identified acaricidal plants}

Local authorities in the study region assisted in identifying 32 herbalists who also named 16 acaricidal species. Using independent reports, the three plants with the highest frequencies (ranks 1, 2, and 3) were chosen for the bioassay test. This research also divided the 16 ethnoveterinary medicinal plants into 13 families, complete with descriptions, traditional preparation methods, botanical names, and local names (Table 2).

The Solanaceae family was the most common (14.58 percent) among independent studies, while Capparaceae was the least popular ( 2.78 percent).

Table 2. Acaricidal plants identified during the study

\begin{tabular}{|c|c|c|c|c|c|c|c|}
\hline Botanical name and voucher number & - Vernacular name & Family & Habit & $\begin{array}{c}\text { Parts } \\
\text { used }\end{array}$ & $\begin{array}{c}\text { Mode of } \\
\text { preparation }\end{array}$ & $\begin{array}{l}\text { Number of } \\
\text { independent } \\
\text { reports (IR) }\end{array}$ & Ranking \\
\hline Phytolacca dodecandra AO 2015/ 003 & Mahoho & Phytolaccaceae & Shrub & Leaves & Infusion & 16 & 1 \\
\hline Cissus quadrangularis AO 2015/010 & Minya & Vitaceae & Herb & Whole & Decoction & 15 & 2 \\
\hline Ipomoea kituiensis AO2015/006 & Obinju mar nam & Convolvulaceae & Shrub & Leaves & Decoction & 13 & 3 \\
\hline Solanum incanum AO 2015/011 & Ochok & Solanaceae & Shrub & Whole & Decoction & 12 & 4 \\
\hline Aloe dawei AO 2015/014 & Ogaka & Aloeceae & Shrub & Leaves & Infusion & 10 & 4 \\
\hline Tagetes minuta AO 2015/ 004 & Nyanjagra & Compositae & Herb & Whole & Infusion & 9 & 6 \\
\hline Ocimum kilimandscharicum AO 2015/ 005 & 5Mweny madongo & Lamiaceae & Shrub & Whole & Decoction & 9 & 6 \\
\hline Melia azedarach AO 2015/012 & Dwele & Meliaceae & Tree & $\begin{array}{l}\text { Leaves, } \\
\text { fruits }\end{array}$ & Decoction & 9 & 6 \\
\hline Datura stramonium AO 2015/015 & Koth- kiyombi & Solanaceae & Herb & Leaves & Infusion & 9 & 6 \\
\hline Ricinus communis AO 2015/ 009 & Obalandagwa & Euphorbiaceae & Shrub & $\begin{array}{l}\text { Leaves, } \\
\text { Fruits }\end{array}$ & Infusion & 8 & 11 \\
\hline Azadirachta indica AO 2015/007 & Mwarubaine & Meliaceae & Tree & Leaves & Decoction & 7 & 12 \\
\hline Lantana camara AO 2015/008 & Onyalo biro & Verbenaceae & Shrub & Leaves & Decoction & 7 & 12 \\
\hline Senna didymobotrya AO 2015/ 002 & Owino & Leguminosae $\mathrm{C}$. & Shrub & Leaves & Infusion & 6 & 14 \\
\hline Euphorbia tirucalli AO 2015/016 & Ojuok & Euphorbiaceae & Tree & $\begin{array}{l}\text { Leaves, } \\
\text { bark }\end{array}$ & Sap & 5 & 14 \\
\hline Cucumis aculeatus AO 2015/ 001 & Otangle & Cucurbitaceae & Herb & Fruit & Decoction & 5 & 15 \\
\hline Maerua edulis AO 2015/013 & Amoyo & Capparaceae & Herb & Leaves & Decoction & 4 & 16 \\
\hline
\end{tabular}

Note: The coding is my personal way of plant identification. AO stands for Alfred Onyango 
Cucumis aculeatus Cogn (Cucurbitaceae) - Otangle -AO 2015/001

This perennial herb is characterized by spiny yellowhooked hairs on the stem ridges and main veins underneath the leaves. The leaves are ovate and three-lobed, either profoundly or shallowly. Male flowers are $11 \mathrm{~mm}$ long, yellow-green, and solitary. It has a green to yellow fruit that is $7 \mathrm{~cm}$ long and has scattered bristle-tipped projections. Cut the fruit, decoct it, and apply it to the animal's coat, concentrating on the infested areas.

\section{Senna didymobotrya (Leguminosae C.) - Owino- AO 2015/002}

This shrub can reach a height of 4.5 meters. The leaves are up to $45 \mathrm{~cm}$ long and have ten to twenty pairs of oval leaflets, each with a fine point at the top. Flowers are bright yellow, up to $1.8 \mathrm{~cm}$ tall, and crowded together in a $45 \mathrm{~cm}$ long raceme. It has ten stamens in its unopened buds, seven of which are fully developed (two or three of which are longer) and three poorly developed. Pods are flattened to a length of $12.5 \mathrm{~cm}$. Grasslands and scrubs are where you'll find them. Poisonous are the leaves, pods, and roots. Leaves may be used either dry or wet. This is pounded, and the resulting infusion is used to wash lice, ticks, and fleainfested animals.

\section{Phytolacca dodecandra L. Herit (Phytolaccaceae) - Mahoho -AO 2015/003}

This clambering plant can reach a height of 9 meters and has long, hanging branches and a tuberous rhizome. The leaves are oval, wide, and glossy, measuring up to 15 $\mathrm{cm}$ in length, with the two sides sometimes unequal. Flowers range in color from greenish-white to purple, scented, and unisexual. Male flowers have fifteen stamens, a five-celled ovary, and an infertile ovary. A five-celled ovary and eight to fifteen short infertile stamens are found in female flowers. The orange-red fruit has five lobes and is fleshy. They can be found on forest edges, scrub areas, and termite mounds. The plant is highly poisonous, and an infusion made from the leaves is used to wash livestock to suppress external parasites.

\section{Tagetes minuta L. (Compositae) - Nyanjagra - AO 2015/004}

This is a tall, stiff herb that can reach a height of 1.8 meters. The leaves are opposite and compound, with small lanceolate leaflets toothed on the edges and a heavy odor. The flower heads are yellow and elongated in a rigid, crowded inflorescence. Florets are tubular and ligulate, and each flower head has about two of each. Pappi have a small number of scales. The whole plant is pounded, and the infested animal is washed several times with the infusion until all ticks and lice are gone.

\section{Ocimum kilimandscharicum Guerk (Lamiaceae) - Mweny madongo- AO 2015/005}

This is a hairy branching shrub with erect or ascending branches that can also be used as a herb. The leaves are ovate to elliptic in shape and have spreading hairs and a rounded apex. Its racemes are simple, terminal whorls of small white to pinkish flowers with a distance between them. The spreading tubes on the petals are about $7 \mathrm{~mm}$ long, and the sepals are about $6 \mathrm{~mm}$ long.

Ipomoea kituiensis Vartke (Convolvuliaceae) - Obinju mar nam- AO 2015/006

This is a sub-erect or twining shrub that can reach a height of 6 meters. It has an ovate to reniform leaf blade 14 $\mathrm{cm}$ long and $13 \mathrm{~cm}$ wide. Flowers are borne in cymes with peduncles ranging in length from 3.5 to $20 \mathrm{~cm}$. The sepals of this plant are lanceolate to ovate and have a linear shape. It has a funnel-shaped corolla that is white, cream, or yellow with a purple center and measures 5 to $8 \mathrm{~cm}$ long. It has an ellipsoidal capsule fruit $15 \mathrm{~mm}$ long and $1.3 \mathrm{~cm}$ thick, with an ovoid ( $7 \mathrm{~mm}$ long) seed that is hairy. The leaves are pounded, and the decoction treats ticks, lice, and fleas in livestock.

\section{Azadirachta indica (Meliaceae) - Mwarubaine- AO 2015/007}

This is a hardy, fast-growing medium-sized tree with a thick leafy oval-shaped canopy that grows from 15 to 20 meters tall. It is an evergreen plant that thrives in arid and semi-arid climates. The leaves are glossy, green, and crowded towards the ends of branches, while the bark is pale to grey-brown and rough. Long sprays of creamy white flowers hang from the plant. When fully ripe, the fruits are oval yellow berries with a diameter of up to $2 \mathrm{~cm}$ and a length of up to $2 \mathrm{~cm}$. A solution made from pounded leaves is used as an anti-tick mist on animals.

\section{Lantana camara L. (Verbinaceae) - Onyalo biro- AO 2015/008}

This scrambling herbaceous shrub can reach a height of 2.4 meters. The stem is prickly and square, especially near the base. The opposite leaves are ovate and up to $8.7 \mathrm{~cm}$ long, rough, and toothed on the edges. The flowers are pink on the outside and yellowish in the center of the flattened head. When the fruits are fully mature, they have a lustrous black appearance. Open bushland, wooded grassland, and dry forest margins are good places to look for the plant. To treat lice, mites, and ticks, whole leaves are crushed, mixed with hot water, and sprayed on the animal's coat.

\section{Ricinus communis L. (Euphorbiaceae) - Obala-ndagwa- AO 2015/009}

This evergreen shrub can reach a height of up to 5 meters. The leaves are green or reddish, glabrous and glaucous, 15-60 cm wide, with alternating long-petiolate, deeply palmately lobed leaves. Male flowers are below, and female flowers are above in broad pyramidal pseudoterminal erect panicles. Female flowers have a showy red stigma on the upper part of the spike, while male flowers have creamy yellow stamens. The fruit is round and deep red, with an ellipsoid or oblong form capsule. Cattle have been confirmed to be poisoned by the seed and seed coat (Kokwaro and Johns 1998; 2013). To control ticks and lice, mature fruit is pulverized, immersed in cold water, and then applied to the animal's coat. 
Cissus quadrangularis L. (Vitaceae) - Minya- AO 2015/010

This is a climbing shrub or herb with tendrils and a succulent four-sided stem. The leaves are simple and toothed in different ways, and they are only present in the younger sections of the plant. Flowers are arranged in umbels. Ticks, lice, and mange are all treated with a decoction made from the pounded whole plant. It has a solid skin-smartening effect.

\section{Solanum incanum L. (Solanaceae) - Ochok- AO 2015/011}

This is a $2 \mathrm{~m}$ tall erect shrub with spiny roots, branches, and leaves. Hairs cover both surfaces of the stems, which are prickly on the midrib of the older leaves. It has mauve or purple flowers that are up to $3.8 \mathrm{~cm}$ long. The anthers are yellow and joined in the flower's center, with three to ten or more flowers in the inflorescence. The fruit is a large yellow berry with a diameter of up to $3.8 \mathrm{~cm}$. The plant can be found on wasteland and the roadside where the soil has been eroded or scraped away. To keep ticks and other external parasites at bay, cattle are washed with a decoction made from whole pounded plants. To kill ticks, the fruit pulp is directly applied to tick-infested areas.

\section{Melia azedarach L. (Meliaceae) - Dwele- AO 2015/012}

This deciduous tree grows up to 15 meters tall and has a glossy grey-brown bark. Petioles and rachis can be up to 40 $\mathrm{cm}$ long, and the leaves are typically 2-pinnate. It has opposite or sub-opposite leaflets up to $5.5 \mathrm{~cm}$ long and 2.5 $\mathrm{cm}$ wide. Small flowers in a broad axillary cymose panicle with a calyx $2.5 \mathrm{~mm}$ long and petals up to $8 \mathrm{~mm}$ long adorn the inflorescence. The fruit comprises fleshy berries that can be up to $2 \mathrm{~cm}$ long and $1.5 \mathrm{~cm}$ wide. People, pets, and poultry are all poisoned by berries. Mange, tick, and lice infestations are treated with leaves and fruits.

\section{Maerua edulis (Capparaceae) - Amoyo- AO 2015/013}

This glabrous spreading shrub or woody herb grows up to 3 meters tall. The leaves are petiolate and simple. It has several flowers on pedicels that are 10 to $25 \mathrm{~mm}$ long. There are no petals on the sepals, 4 to $9 \mathrm{~mm}$ long. The stamens are 15 to $30 \mathrm{~mm}$ long, and the androphore is about $1 \mathrm{~mm}$ longer than the receptacle. The fruits are globose and yellow or orange, with a spindle-shaped ovary that is 4 to 6 $\mathrm{mm}$ long. As a tick prevention solution, the leaves are pounded, and the infusion is applied to the animals.

\section{Aloe dawei Berger (Aloeaceae) - Ogaka- AO 2015/014}

This densely branched, the leafy shrub grows 1 to 2 meters high. The leaves are dark green, with a 60 to $90 \mathrm{~cm}$ tall inflorescence. The stalks are dark red-brown, and the racemes are densely flowered with red flowers. The plant is most commonly found in western Kenya's rocky bushland. Animals are washed with a leaf decoction to cure skin diseases and control external parasites, including ticks.

Datura stramonium L. (Solanaceae) - Koth- kiyombi- AO 2015/015

This herb can grow up to 1.5 meters tall. The stem is smooth and often divides into two branches. The leaves are ovate, pointed, and lobed or deeply toothed. It has white flowers that bloom singly where the stem branches, with a calyx up to $3.8 \mathrm{~cm}$ long and a funnel-shaped, folded corolla with young stamens attached at the base of the corolla tube. The ovary has four cells. The fruit can grow up to $5 \mathrm{~cm}$ in length and is extremely prickly. The leaves poison humans and animals. They are pounded, and the resulting solution is used to treat livestock for ticks and ringworm.

\section{Euphorbia tirucalli (Euphorbiaceae) - Ojuok- AO 2015/016}

This succulent shrub or tree can grow up to $6 \mathrm{~m}$ tall and is found in bushland, thickets, and coastal bushland. The bark is thick and straight-stemmed. In dense masses, the branches are smooth, green, and cylindrical. It has small leaves that can grow up to $6 \mathrm{~mm}$ long. The flowers, which are cream or yellow-green, develop in short, terminal clusters. Its fruit is a three-lobed capsule $6 \mathrm{~mm}$ across, hard, and purple-green. This plant's latex is highly poisonous, particularly to the eyes, and is used as a fish poison as well as an insecticide.

\section{Distribution in plant habit and usage as anti-tick}

There were also differences in plant consumption based on their habit (Figure 2), with shrubs having the highest usage $(56.25 \%)$, followed by herbs $(29.17 \%)$, and finally trees $(14.58 \%)$. The leaf was the most commonly used plant part $(56.63 \%)$, followed by the entire plant $(27.11 \%)$, fruit $(13.25 \%)$, and bark $(3.01 \%)$. In the independent study, the habit percentage was determined as a percent of the total number of habits listed by all informants:

Habit percentage $=($ Habit independent report $/ 144) X 100$;

Where; Habit= total number of times a habit is mentioned in the independent; $144=$ cumulative number of habits mentioned in the independent report.

\section{Knowledge of acaricidal plants}

The age groups 68 to 77 and 78 to 87 years had the most plants cited (14 each) from the 32 interviews conducted using a questionnaire on herbalists between the ages of 28 and 87 years, while the age group 28 to 37 years had the fewest (4). There was a clear association $(r=0.81)$ between age and the number of plants cited. The older the informants, the more plants they mentioned (Figure 3).

\section{Traditional methods of preparation of drugs}

Various methods of preparing herbal medicine were used, with decoction being the most favored form $(56.25 \%)$, followed by infusion $(40.28 \%)$ and sap $(3.47 \%)$. Pounding proved to be the preliminary procedure for any medicinal preparation, so it was universal.

Three plants, Phytolacca dodecandra (leaves), Cissus quadrangularis (leaves and stems), and Ipomoea kituiensis (leaves), were chosen for chemical and bioactivity testing because they were the top three most commonly used plants (Table 3 ). 


\section{Yield of crude plant extracts}

Phytolacca dodecandra extract yielded the highest percentage yield of $8.87 \%$ among the tested Methanol/DCM (1:1 v/v) extracts, while I. kituiensis yielded $7.17 \%$, and C. quadrangularis yielded the lowest (6.33\%). P. dodecandra had the highest percentage yield $(10.24 \%)$ of the tested water extracts, while $C$. quadrangularis and I. kituiensis yielded just $8.56 \%$ and $8.22 \%$, respectively. Water produced a higher mean percentage yield $(9.01 \%)$ than methanol in DCM $(1: 1 \mathrm{v} / \mathrm{v})$ solvent, which produced a $7.46 \%$ yield (Table 4$)$. The original sample weighed $160 \mathrm{~g}$.

\section{Phytochemical analysis of crude plant extracts for secondary metabolites}

Except for $P$. dodecandra, all plants tested positive for flavonoids, alkaloids, tannins, terpenoids, and saponins in organic and aqueous extracts. However, the organic and aqueous extracts of P.dodecandra yielded unfavorable results for flavonoids (Table 5).

\section{Lethal concentration ( $\left.\mathrm{LC}_{50}\right)$ of brine shrimp larvae}

Except for organic extracts of I. kituiensis, which showed comparatively low toxicity at $10 \mu \mathrm{g} / \mathrm{ml}$, both aqueous extracts and organic extracts were extremely toxic at $10 \mu \mathrm{g} / \mathrm{ml}$ (Table 6). Similarly, at $100 \mu \mathrm{g} / \mathrm{mL}$, both aqueous and organic extracts were highly toxic, whereas $I$. kituiensis organic extracts were only mildly toxic. Both aqueous and organic extracts of all plants were extremely toxic at $1000 \mu \mathrm{g} / \mathrm{mL}$.

In vitro acaricidal activity of crude plant extracts

An in vitro evaluation of the acaricidal activity of each crude plant extract revealed that $P$. dodecandra leaves were the most effective, followed by $C$. quadrangularis (whole plant) and I. kituiensis leaves in that order (Table 3).

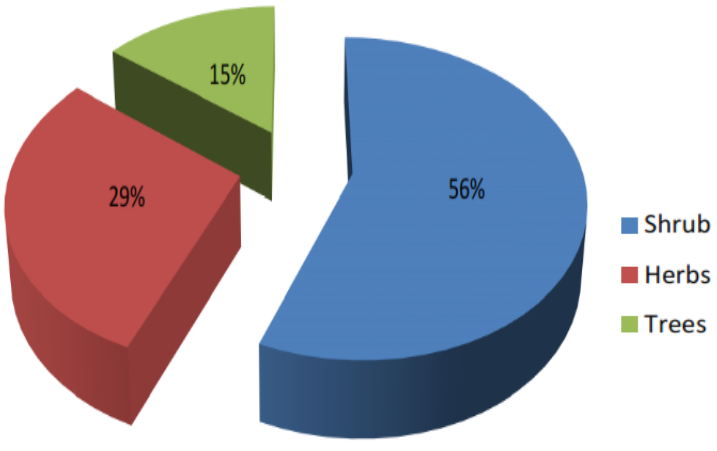

Figure 2. Plants usage according to their habit

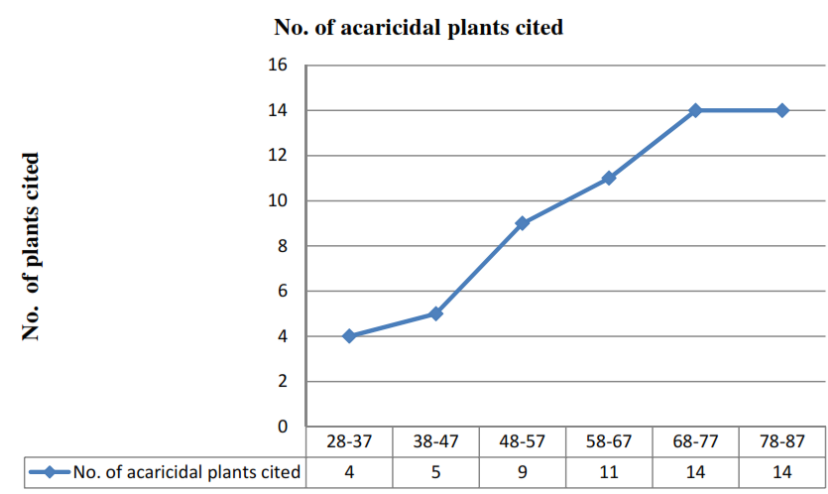

Figure 3. Age groups of informants and the number of medicinal plants cited

Table 3. Selected priority plants

\begin{tabular}{lcc}
\hline \multicolumn{1}{c}{ Plant species } & Part collected & Rank \\
\hline Phytolacca dodecandra & Leaves & 1 \\
Cissus quadrangularis & Whole & 2 \\
Ipomoea kituiensis & Leaves & 3 \\
\hline
\end{tabular}

Table 4. Yield of organic and aqueous plant extracts measured in grams after extraction

\begin{tabular}{lcccc}
\hline \multirow{2}{*}{ Plant species } & \multicolumn{2}{c}{ Methanol in DCM extract (1:1 v/v) } & \multicolumn{2}{c}{ Water extract } \\
\cline { 2 - 5 } & Yield (grams) & Percentage yield (\%) & Yield (grams) & Percentage yield (\%) \\
\hline Cissus quadrangularis (whole) & 10.13 & 6.33 & 13.70 & 8.56 \\
Ipomoea kituiensis (leaves) & 11.47 & 7.17 & 13.15 & 8.22 \\
Phytolacca dodecandra (leaves) & 14.19 & 8.87 & 16.38 & 10.24 \\
Average & 11.93 & 7.46 & 14.41 & 9.01 \\
\hline
\end{tabular}

Table 5. Phytochemical analysis of each crude extract for secondary metabolites

\begin{tabular}{|c|c|c|c|c|c|c|}
\hline Plant & Crude extract & Alkaloids & Flavonoids & Saponins & Tannins & Terpenoids \\
\hline \multirow[t]{2}{*}{ Cissus quadrangularis } & Methanol in DCM $(1: 1 \mathrm{v} / \mathrm{v})$ & + & + & + & + & + \\
\hline & Water & + & + & + & + & + \\
\hline \multirow[t]{2}{*}{ Ipomoea kituiensis } & Methanol in DCM $(1: 1 \mathrm{v} / \mathrm{v})$ & + & + & + & + & + \\
\hline & Water & + & + & + & + & + \\
\hline \multirow[t]{2}{*}{ Phytolacca dodecandra } & Methanol in DCM $(1: 1 \mathrm{v} / \mathrm{v})$ & + & - & + & + & + \\
\hline & Water & + & - & + & + & + \\
\hline
\end{tabular}

Note: +: Present, -: Absent 


\section{Larvicidal activity of $\boldsymbol{P}$. dodecandra extracts}

When the larvicidal activity of organic extracts of $P$. dodecandra at $5 \mathrm{mg} / \mathrm{mL}$ and $10 \mathrm{mg} / \mathrm{mL}$ was compared to that of almatix, both concentrations were not substantially (p>0.05) different inactivity, meaning that $5 \mathrm{mg} / \mathrm{mL}$ and $10 \mathrm{mg} / \mathrm{mL}$ organic extracts of $P$. dodecandra had similar larvicidal activity to that of almatix (Figure 4). However, compared to almatix, the aqueous extracts demonstrated significantly lower activity $(\mathrm{p}<0.05)$. At $2.5 \mathrm{mg} / \mathrm{mL}$, both $P$. dodecandra extracts had significantly lower larvicidal activity $(\mathrm{p}<0.05)$ than almatix.

\section{Larvicidal activity of $\boldsymbol{I}$. kituiensis extracts}

As compared to almatix, both aqueous and organic extracts of $I$. kituiensis had significantly lower $(\mathrm{p}<0.05)$ larvicidal activity at all concentrations (Figure 5). At the lowest concentration of $I$. kituiensis $(2.5 \mathrm{mg} / \mathrm{mL})$, the difference in larvicidal activity was significantly higher.
Larvicidal activity of Cissus quadrangularis extracts

Except for the organic extract at $10 \mathrm{mg} / \mathrm{mL}$, the aqueous and organic extracts of $C$. quadrangularis had significantly lower larvicidal activity $(\mathrm{p}<0.05)$ at all concentrations. Organic extract of $C$. quadrangularis demonstrated $100 \%$ mortality at a concentration of 10 $\mathrm{mg} / \mathrm{mL}$, which was not substantially different from almatix activity ( $\mathrm{p}>0.05$ ) (Figure 6). Compared to P. dodecandra and I. kituensis, C. quadrangularis crude extracts have the lowest larvicidal activity.

\section{Acute toxicity of the crude plant extracts to tick larvae and estimation of lethal concentration $\left(\mathbf{L C}_{50}\right)$}

Organic extracts had higher mortality in each plant species than aqueous extracts, except for $C$. quadrangularis, where aqueous was more active than organic at $5 \mathrm{mg} / \mathrm{mL}$. Despite this, organic extracts of P.dodecandra showed the highest LC50 at $3.85 \mathrm{mg} / \mathrm{mL}$. At $13.90 \mathrm{mg} / \mathrm{mL}, C$. quadrangularis aqueous extracts had the lowest LC50 (Table 7).

Table 6. Lethal concentration (LC50) of brine shrimp larvae

\begin{tabular}{|c|c|c|c|c|c|c|c|c|c|c|}
\hline \multirow{3}{*}{ Plant name } & \multicolumn{8}{|c|}{ Average mortality at various concentrations of extracts $(\mu \mathrm{g} / \mathrm{mL})$} & \multirow{2}{*}{\multicolumn{2}{|c|}{$\mathbf{L C}_{50}(\boldsymbol{\mu g} / \mathrm{mL})$}} \\
\hline & \multicolumn{2}{|c|}{$0 \mu \mathrm{g} / \mathrm{mL}$} & \multicolumn{2}{|c|}{$10 \mu \mathrm{g} / \mathrm{mL}$} & \multicolumn{2}{|c|}{$100 \mu \mathrm{g} / \mathrm{mL}$} & \multicolumn{2}{|c|}{$1000 \mu \mathrm{g} / \mathrm{mL}$} & & \\
\hline & Water & Org & Water & Org & Water & Org & Water & Org & Water & Org \\
\hline P. dodecandra & 0.0 & 0.0 & 9.66 & 8.33 & 10.0 & 10.0 & 10.0 & 10.0 & 35.98 & 39.97 \\
\hline C. quadrangularis & 0.0 & 0.0 & 9.33 & 8.0 & 10.0 & 9.33 & 10.0 & 10.0 & 38.31 & 113.1 \\
\hline I. kituensis & 0.0 & 0.0 & 10.0 & 4.0 & 10.0 & 6.33 & 10.0 & 10.0 & 136.96 & 4.17 \\
\hline Water & 0.0 & & 0.0 & & 0.0 & & 0.0 & & 1708.23 & \\
\hline DMSO & & 0.00 & & 0.00 & & 0.00 & & 0.00 & & 1708.23 \\
\hline
\end{tabular}

Note: $\mathrm{LC}_{50}<100$ : Strongly/highly toxic, $\mathrm{LC}_{50}>100<500$ : moderately toxic $\mathrm{LC}_{50}>500<1000$ : weakly toxic $\mathrm{LC}_{50}>1000$ : Non toxic, Org= Methanol: DCM $(1: 1 \mathrm{v} / \mathrm{v})$

Table 7. Acute toxicity and $\mathrm{LC}_{50}$ of crude extracts to the B.decoloratus tick larvae

\begin{tabular}{|c|c|c|c|c|c|c|c|c|c|c|}
\hline \multirow{3}{*}{ Plant name } & \multicolumn{8}{|c|}{ Average mortality at various concentrations $(\mathrm{mg} / \mathrm{mL})$} & \multirow{2}{*}{\multicolumn{2}{|c|}{$\mathrm{LC}_{50}(\mathrm{mg} / \mathrm{mL})$}} \\
\hline & \multicolumn{2}{|c|}{$0 \mathrm{mg} / \mathrm{mL}$} & \multicolumn{2}{|c|}{$2.5 \mathrm{mg} / \mathrm{mL}$} & \multicolumn{2}{|c|}{$5 \mathrm{mg} / \mathrm{mL}$} & \multicolumn{2}{|c|}{$10 \mathrm{mg} / \mathrm{mL}$} & & \\
\hline & Water & Org & Water & Org & Water & Org & Water & Org & Water & Org \\
\hline P. dodecandra & 0.0 & 0.0 & 7.33 & 15.33 & 78.17 & 100 & 95.66 & 100 & 4.83 & 3.85 \\
\hline C. quadrangularis & 0.0 & 0.0 & 1.33 & 16.33 & 20.67 & 8.83 & 21.5 & 100 & 13.9 & 5.56 \\
\hline I. kituensis & 0.0 & 0.0 & 13.67 & 16.5 & 82.33 & 84.83 & 59.83 & 82.5 & 6.65 & 5.23 \\
\hline Almatix & 100 & 100 & 100 & 100 & 100 & 100 & 100 & 100 & 2.36 & \\
\hline
\end{tabular}

Note: Aq: Water, Org: Methanol in dichloromethane (1:1 v/v)

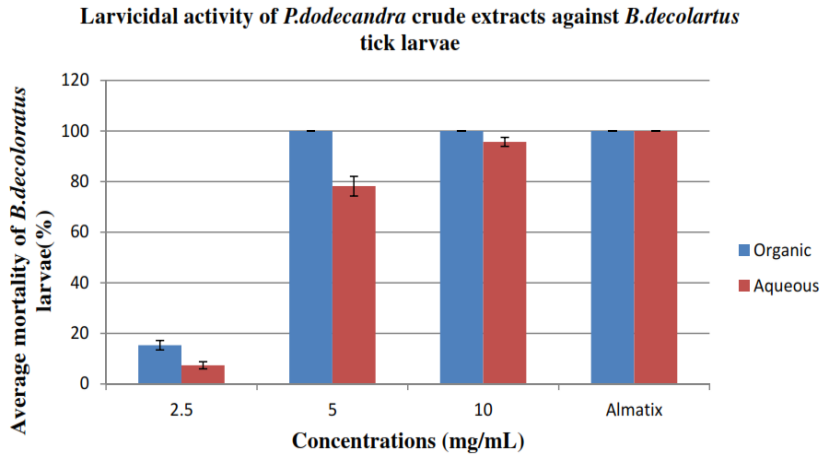

Figure 4. Average $( \pm$ Standard deviation $)$ mortality of $B$. decoloratus tick larvae due to $P$. dodecandra extracts at various concentrations

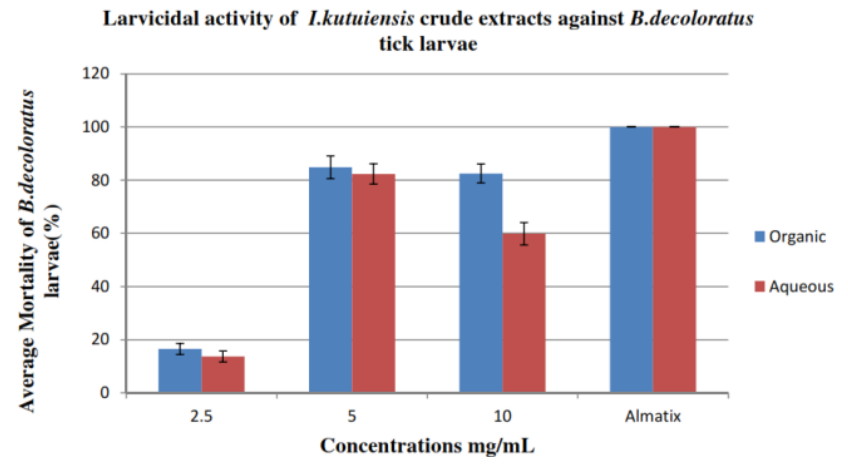

Figure 5. Average ( \pm Standard deviation) mortality of $B$. decoloratus tick larvae due to I. kituiensis extracts at various concentrations 


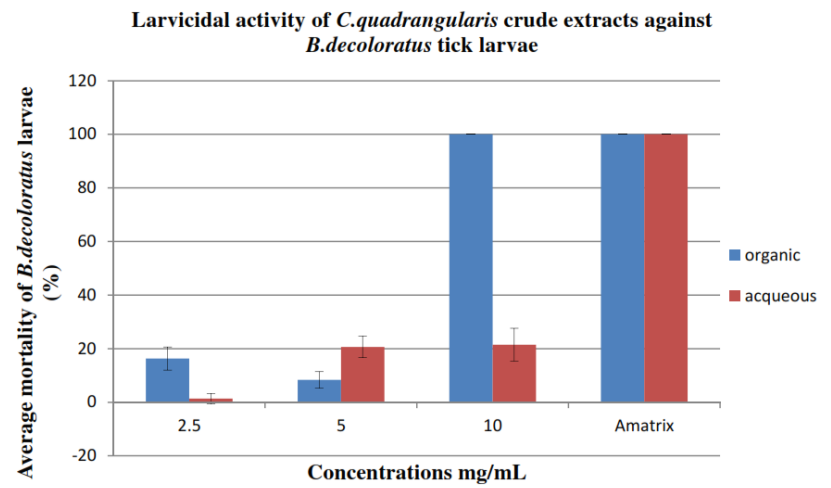

Figure 6. Average ( \pm Standard deviation) mortality of B.decoloratus tick larvae due to Cissus quadrangularis extracts at various concentrations

\section{Discussion}

Acaricidal and insecticidal properties of plant extracts have seen widespread use against phytophagous pests over the last decade (Isman 2006). Tick management is a skill that traditional healers in Suba Sub-County have mastered. Individuals with advanced plant knowledge appeared to be the local authorities on medicinal practices. They keep the information hidden and to themselves, as previously mentioned (Wanzala et al. 2012), and only share it with others in exchange for valuables. Herbalists believe that medicines will not successfully treat various diseases if herbal knowledge is not guarded with zeal.

Nonetheless, most ethno-practitioners openly discussed and shared their information after receiving an inducement fee (ranging from $\$ 5$ to $\$ 10$ ) during this research. The majority of those interviewed in this study were men between 28 and 87, with just five women among the 32 people interviewed. The fact is, in most traditional livestock-raising cultures, it is men who tend to take care of sick livestock, owing to their masculine disposition (hence their ability to keep animals during drug administration) and more substantial knowledge of medicinal plant use in tick control (Magwede et al. 2014). People with high literacy levels were found to have the same knowledge of medicinal plants as those who were illiterate, probably due to their shared interests. This result is consistent with Beltran et al. (2014) and Mesfin et al. (2014), who discovered that the informants' level of education had little bearing on their ethnobotanical knowledge.

Due to the delicate nature of traditional medicine interviews, the questionnaires had an introductory preamble to explain the purpose of the survey to all respondents. Only one respondent per household was interviewed to prevent bias in the answers. The respondent's age and the number of acaricidal plants cited by individuals had a strong association $(\mathrm{r}=0.81)$. The older a person gets, the more plants they know and how to use them. Age is a factor that is highly correlated with the number and uses of plants known by individuals in many cases and in different societies, which is consistent with the findings of Beltran et al. (2014) and Magwede et al. (2014), who found that the older an individual is, the greater their knowledge of plants and their uses as anti-tick preparations because ethnobotanical knowledge tends to accumulate.

The study identified 16 acaricidal plants and provided a concise botanical description of each of the plants identified as having acaricidal properties in the Suba SubCounty. The descriptions of these plants add to what has already been known about them (Lind and Tallantine 1975; Agnew and Agnew 1994; Kokwaro and Johns 1998; 2013; Demissew 2006; Agnew 2013). Solanaceae (14.58\%), Phytolaccaceae (11.11\%), and Meliaceae were the most widely used plant families in tick control among these species $(11.11 \%)$. Plants from the Solanaceae family were used in tick control more frequently than any other plant family in the sub-county. This can be explained by the fact that the family contains a diverse range of secondary metabolites such as alkaloids, saponins, terpenoids, and tannins. These compounds may contribute independently or jointly to the observed acaricidal activity against ticks. The various plants mentioned fall into three plant habits: shrubs had the highest percentage of total independent reports $(56.63 \%)$, followed by herbs $(29.17 \%)$, and trees had the lowest $(14.58 \%)$. Leaves, fruits, bark, and the whole plant are among the plant parts used to make medicines. The leaf was the most frequently used $(56.63 \%)$, followed by the whole plant $(27.11 \%)$ and the fruit $(27.11 \%)(13.25 \%)$. The bark was the least commonly used (3.01\%). This contradicts the findings of Magwede et al. (2014), who discovered that the bark was the most preferred form of plant material in tick control, followed by leaves and fruits, and the root was the least preferred part. In some plants, such as $C$. quadrangularis, cattle were given more than one part (leaves, stems, and fruits).

In this study, drug preparation entailed extracting the active principles from the parent plants with medicinal value. The pounding was the most common and widely used primary method for all medicinal preparations. Other methods included the most commonly used ones like decoction, infusion, and sap. Among these methods, making a decoction was the most popular, with sap being used only infrequently. The decoction method is widely used because it is simple, convenient, and inexpensive (Mohammed et al., 2013). All drug preparations were applied by washing the infested cattle's coats, whatever method was used.

Phytolacca dodecandra, I. kituiensis, and $C$. quadrangularis were the three most widely used plant species in this study, and they are commonly used as acaricides. This is because these organisms possess a diverse set of biologically active elements. Flavonoids, tannins, saponins, terpenoids, and alkaloids are some of the pharmacologically essential phytochemicals researched and found to have anti-malarial, molluscicidal, pesticidal, and acaricidal properties (Parveen et al. 2014). Except for flavonoids, preliminary phytochemical screening of $P$. dodecandra crude extracts revealed positive results for tannins, flavonoids, alkaloids, saponins, and terpenoids. Following research that has been previously published (Mekonnen et al. 2012). Tannins, flavonoids, alkaloids, saponins, and terpenoids were observed in $C$. quadrangularis, consistent with a previous study by Ruskin 
et al. (2014) that found related compounds. I. kituiensis produced positive results for all of the secondary metabolites studied, which is the first time reported. The findings of this research are consistent with those of Essiett and Obioboho (2014). They concluded that tannins, flavonoids, alkaloids, saponins, and terpenoids are the critical metabolites of Ipomoea batatas in a study of a member of the same genus.

Phytochemicals are gaining popularity due to exciting discoveries related to their biological activities. The three most commonly used acaricidal plants were subjected to phytochemical screening to assess the presence of tannins, saponins, flavonoids, terpenoids, and alkaloids. Tannins are widely distributed in nature and are commonly found as active principles in plants used in traditional medicine. Condensed tannins have a strong ability to interact with metal ions and macromolecules and form soluble complexes with electron-donor groups found in alkaloids (Rey et al. 1999). This may be one explanation for their toxicity to insects, fungi, bacteria, and plenty of other species. The morphological changes in the midgut epithelium of Aedes aegypti larvae caused by this active fraction are similar to those seen with tannic acid (Rey et al. 1999). On a side note, the ethanolic extract of stem barks from this Melia species has shown potential as an acaricide against the larvae of the common cattle tick, Rhipicephalus sanguineus, and Boophilus spp. (Kamani et al. 2008). Insecticidal, growth-inhibiting, anti-molting, and repellent properties have been discovered in bioactive plant compounds such as phenolics, terpenoids, and alkaloids (Ghosh et al., 2007). On a side note, the ethanolic extract of stem barks from this Melia species has shown potential as an acaricide against the larvae of the common cattle tick, $R$. sanguineus, and Boophilus spp. (Kamani et al. 2008). Insecticidal, growth-inhibiting, anti-molting, and repellent properties have been discovered in bioactive plant compounds such as phenolics, terpenoids, and alkaloids (Ghosh et al., 2007).

According to the World Health Organization, over 200,000 people die each year due to pesticide poisoning (Christine et al., 2015). A brine shrimp test was recommended to predict crude plants' toxicity, pharmacological actions, and pesticide effects (Nguta et al., 2013). A crude plant extract is considered active up to a $240 \mathrm{~g} / \mathrm{ml}$ concentration. The brine shrimp bioassay is a recommended simple method because it is fast, effective, and inexpensive, and it correlates relatively well with drug cytotoxicity in mammals in most cases (Odhiambo et al., 2014). The treatment calculates the median lethal concentrations of active compounds and extracts (Nguta et al., 2013). The plants under review showed high toxicity levels using brine shrimp larvae. Organic extracts of $C$. quadrangularis with LC50 values of $113.10 \mathrm{~g} / \mathrm{mL}$ and aqueous extracts of I. kituiensis with LC50 values of $136.96 \mathrm{~g} / \mathrm{mL}$ were both mildly toxic. Secondary metabolites, especially alkaloids, saponins, and tannins, are responsible for toxicity. Alkaloids interact with cell membranes and damage cell integrity, leading to apoptosis or cell death since the cells' membranes are broken and can no longer withstand osmotic forces (Rosenkranz and Wink
2007). P. dodecandra water and organic extracts were extremely toxic in this sample, with LC50 values of 35.98 $\mathrm{g} / \mathrm{mL}$ and $39.97 \mathrm{~g} / \mathrm{mL}$, respectively. This contrasted with a study by Namulindwa et al. (2015), who found aqueous leaf extract of $P$. dodecandra to be moderately toxic. The aqueous extracts of $C$. quadrangularis were extremely toxic, with LC50 values of $38.31 \mathrm{~g} / \mathrm{mL}$, while the organic extracts were moderately toxic, with LC50 values of 113.1 $\mathrm{g} / \mathrm{mL}$. This contradicted Enechi et al. (2013) findings, who found that $C$. quadrangularis ethanol extract is non-toxic. To the brine shrimp, I. kituiensis aqueous extracts were moderately toxic $(\mathrm{LC} 50=136.96 \mathrm{~g} / \mathrm{mL})$, while its organic extracts were extremely toxic $(\mathrm{LC} 50=4.17 \mathrm{~g} / \mathrm{mL})$. While toxicity reports on some Ipomoea species have been published previously, this is the first recorded toxicity analysis on this plant species. Ipomoea carnea, for example, is a poisonous plant that grows in tropical areas (Guilherme et al., 2012).

Using Boophilus decoloratus tick larvae, the in vitro acaricidal behavior of the selected plant species from the region was checked. The in vitro acaricidal activity requirements were modified from Ducornez et al. (2005). Larvae mortality was determined by lack of movement after 30 minutes of observation after exposure to rudimentary extracts (I. kituiensis, $P$. dodecandra, and $C$. quadrangularis) and the standard medication, almatix. The data showed that the concentrations of the treatments were strongly linked to the mortality of the larvae $(\mathrm{p}<0.05)$. The mortality of the larvae increased as the concentration of plant extracts increased. This finding is consistent with Belmain et al. (2001), who found that lower concentrations of 5 to $10 \%$ dose resulted in fewer tick deaths in Lippia javanica trials than higher doses. In this study, the lowest dose $(2.5 \mathrm{mg} / \mathrm{mL})$ resulted in low mortalities (less than $20 \%$ ), while higher doses resulted in higher mortalities.

The larvicidal behavior of all the aqueous extracts examined differed substantially from almatix. Only organic C. quadrangularis extracts at $10 \mathrm{mg} / \mathrm{mL}$, and organic $P$. dodecandra extracts at $5 \mathrm{mg} / \mathrm{mL}$ and $10 \mathrm{mg} / \mathrm{mL}$ were significantly different $(\mathrm{p}>0.05)$ from the positive control among the tested organic extracts for larvicidal activity. Except for two concentrations ( 5 and $10 \mathrm{mg} / \mathrm{mL}$ ) of $P$. dodecandra, which were not significantly different because they evoked $100 \%$ kill ( $p>0.05)$, there were substantial differences in larvicidal activity among various concentrations of each plant in both aqueous and organic extracts. There was a considerable difference in bioactivity between the three classes of plants, according to the results of a one-way ANOVA followed by a Dunnet t-test. The efficacy of drugs is determined by the types of secondary metabolites contained in plant extracts. The larvicidal effect of these plant extracts on larvae may be due to the direct coercive action of ascaridole monoterpenes on the cardiovascular and respiratory systems, as well as potential nervous system attacks. The nervous system of Rhipicephalus lunulatus is affected by this drug (Miegoue et al., 2013).

According to the results of the organic extracts of $\mathrm{P}$. dodecandra, C. quadrangularis, and I. kituiensis were significantly $(\mathrm{p}<0.05)$ affected by plant species and crude 
plant extract concentration at the end of 24 hours contact toxicity bioassays. At doses of 5 and $10 \mathrm{mg} / \mathrm{mL}, P$. dodecandra, C. quadrangularis, and I. kituiensis elicited a maximum $(100 \%)$ kill of tick larvae for organic extract. This may be explained by the chemical constituents of the other similar member of the same genus, Ipomoea alba, having contact toxicity properties. This plant was discovered to be high in indolizidine alkaloids, which were found to cause acute toxicity to the central nervous system in mice and rats, resulting in convulsions and tremors, among other symptoms (Guilherme et al. 2012). The findings estimated the real vulnerability of tick larvae populations to the effects of botanicals using bioassays and concentration-mortality regression. The LC50 of all the plant extracts was between 3.85 and $6.65 \mathrm{mg} / \mathrm{mL}$, suggesting that Boophilus spp. was highly vulnerable to the effects of the crude plant products. The highest LC50 was found in a water extract of $C$. quadrangularis (whole), which can be clarified because the extraction method used did not adequately concentrate active ingredients before use, as the same plant in organic solvent had a lower acute lethal concentration. Organic extracts of $C$. quadrangularis had a threefold higher LC50 than aqueous extracts of $P$. dodecandra. Both organic extracts had a higher acaricidal effect than aqueous extracts. The LC50 estimates suggested that the crude extracts were toxic to the study tick. The populations of larvae tick stages were more susceptible to botanical extracts.

In conclusion, the findings provide a theoretical basis for using botanicals to reduce the burden of blue ticks in cattle. Both organic and aqueous crude extracts of $P$. dodecandra (LC50: aqueous, 4.83 and organic, 3.85 $\mathrm{mg} / \mathrm{mL}$ ), C. quadrangularis (LC50: aqueous, $13.90 \mathrm{mg} / \mathrm{mL}$ and organic, $5.56 \mathrm{mg} / \mathrm{mL}$ ), and I. kituiensis (LC50: aqueous, $6.65 \mathrm{mg} / \mathrm{mL}$ and organic, $5.23 \mathrm{mg} / \mathrm{mL}$ ) show larvicidal effects in ticks $C$. quadrangularis (LC50: aqueous, $13.90 \mathrm{mg} / \mathrm{mL}$ and organic, $5.56 \mathrm{mg} / \mathrm{mL}$ ) and $I$. kituiensis (LC50: aqueous, $6.65 \mathrm{mg} / \mathrm{mL}$ and organic, 5.23 $\mathrm{mg} / \mathrm{mL}$ ) both have larvicidal effects in ticks, and thus could be used in vitro to mitigate the blue tick issue, which justifies why these medicinal plants have been used to manage this type of tick that affects cattle in Suba SubCounty. Intriguingly, crude extracts had a substantial mean percentage of larvicidal activity against the study tick at higher concentrations. It supports the common use of these plant materials as cattle protectants against harmful tick pests. The findings confirm the acaricidal efficacy of the three plant species in blue tick control, making all of the extracts attractive candidates for evaluation as livestock protectants against $B$. decolocrotus ticks in general.

In DCM $(1: 1 \mathrm{v} / \mathrm{v})$ solvent, water gave a higher yield than methanol, so it should be favored over the latter. Phytochemical analysis revealed that all of the tested plants (except $P$. dodecandra, which lacked flavonoids) contained compounds linked to acaricidal activity, confirming their utility as an anti-blue tick strategy in Suba. Toxic to brine shrimp were $P$. dodecandra, C. quadrangularis, and $I$. kikuiensis. The crude plant extracts are expected to be viable alternatives to traditional acaricides. Since the plants they cited had the potential to control blue ticks, this demonstrates the expertise of the herbalists as a repository of acaricidal plant information. This would most certainly aid in improving livestock health and, as a result, improved livelihood. For humans, this means less hunger and better nutrition.

\section{REFERENCES}

Agnew ADC, Agnew S. 1994. Upland Kenya flowers: A flora of the Ferns and Herbaceous Flowering Plants of Upland Kenya Second Edition. East African Natural History Society, Nairobi, Kenya.

Agnew ADQ. 2013. Upland Kenya Wild Flowers and Ferns, Second Edition. East African Natural History Society, Nairobi, Kenya.

Beentje HJ. 1994. Kenya Trees, Shrubs, and Lianas. National Museums of Kenya, Nairobi, Kenya.

Belay D, Getachew E, Azage T, Hegde BH. 2013. Farmers' perceived livestock production constraints in Ginchi watershed area: Result of participatory rural appraisal. Intl J Livest Prod 4: 128-134. DOI: 10.5897/IJLP2013.0164.

Belmain SR, Neal GE, Golob P. 2001. Insecticidal and vertebral toxins associated with the use of ethnobotanicals used as post-harvest protectants in Ghana. Food Chem Toxicol 39: 287-291. DOI: 10.1016/S0278-6915(00)00134-4.

Beltran RL, Ortiz SA, Reyes GV. 2014. Factors affecting ethnobotanical knowledge in a Mestico community of the Sierra de Huautla Biosphere Reserve, Mexico. J Ethnobiol Ethnomedicine 10: 1-66. DOI: $10.1186 / 1746-4269-10-14$

Christine T, Nyabayo CT, Matasyoh JC, Mwendia C. 2015. Chemical composition and acaricidal activity Of Salvia nilotica essential oil against Rhipicephalus appendiculatus. Adv Med Plant Res 3: 46-54.

Demissew S. 2006. Convolvulaceae. Flora of Ethiopia and Eritrea 5: 227231.

Di Giulio G, Lynen G, Morzaria S, Oura C, Bishop R. 2009. Live immunization against East Coast Fever. Trends Parasitol 25: 85-92. DOI: $10.1016 /$ j.pt.2008.11.007.

Ducornez S, Barre N, Miller RJ, de Garine-Wichatitsky M. 2005. Diagnosis of amitraz resistance in Boophilus microplus in New Caledonia with the modified Larval Packet Test. Vet Parasitol 13: 285-292. DOI: 10.1016/j.vetpar.2005.04.018.

Enechi O, Igbonekwu N, Ugwu P. 2013. Effects of ethanol extract of Cissus quadrangularis on induced gastric ulcer in rats. Afr $\mathrm{J}$ Biotechnol 12: 6197- 6202. DOI: 10.5897/AJB2013.12898.

Essiett UA, Obioboho GE. 2014. Phytochemical, nutrients, and antinutrients of the Ipomoea triloba, Ipomoea batatas, Ipomoea involucrata leaves. Intl J Res 1: 1412-1418.

Finney DJ. 1971. Probit Analysis, Third Edition. Cambridge University Press, London, UK.

Gakuya DW, Mulei CM, Wekesa SB. 2005. Use of ethnoveterinary remedies in the management of foot and mouth disease lesions in a dairy herd. Afr J Tradit Complement Altern Med 8: 165-169. DOI: 10.4314/ajtcam.v8i2.63204.

Ghosh S, Azhahianambi P, Yaday M. 2007. Upcoming and future strategies of tick control. J Vector Borne Dis 44: 79-89.

Government of Kenya (GoK). 2009. Summary of Livestock Data 20022006. Ministry of Planning and National Development, Department of Resource Survey and Remote Sensing, Nairobi, Kenya.

Government of Kenya (GoK). 2012. Kenya's Population and Housing 2009 Census. Kenya National Bureau of Statistics, Nairobi, Kenya.

Green LW, Richard L, Potvin L. 1996. Ecological foundations of health promotion. Am J Health Promot 10: 270-281. DOI: 10.4278/08901171-10.4.270.

Guilherme E, Riad N, Antonio D, Edna F, Mateus L, Ingrit E, Maria M, Suzana P, Ivana B. 2012. Toxicity of Ipomoea alba. Pharmacologyonline 3: 29-41.

Isman MB. 2006. Botanical pesticides, deterrents, and repellents in modern agriculture and an increasingly regulated world. Ann Rev Entomol 51: 45-56. DOI: 10.1146/annurev.ento.51.110104.151146.

Jigna P, Sumitra C. 2007. Antibacterial and phytochemical studies of twelve species of Indian medicinal plants. Afr J Biomed Res 10: 175181. 
Jongejan F, Uilenberg G. 2004. The Global Importance of Ticks. Cambridge University Press, London, United Kingdom. DOI 10.1017/S0031182004005967.

Juliet S, Ravindran R, Ramankutty S, Gopalan A, Nair S, Kavillimakki A, Bandyopadhyay A, Rawat A, Ghosh S. 2012. Jatropha curcas leaf extract-a possible alternative for population control of Rhipicephalus (Boophilus) annulatus. Asian Pac J Trop Dis 10: 225 229. DOI: 10.1016/S2222-1808(12)60051-6.

Kamani J, Yidawi JP, Onovoh E, Mohammed S, Pam DA, Awulu JS, Fernandez-Salas A. 2008. In vitro comparative acaricidal efficacy of azadirachtin and amitraz on Boophilus decoloratus larvae. Niger Vet J 3: 975-980.

Kokwaro JO, Johns T. 1998. Luo Biological Dictionary, First Edition. East African Educational Publishers Ltd, Nairobi, Kenya.

Kokwaro JO, Johns T. 2013. Luo Biological Dictionary, Second Edition. East African Educational Publishers Ltd, Nairobi, Kenya.

Lind EM, Tallantire AC. 1975. Some Common Flowering Plants of Uganda, Second Edition. Oxford University Press, Nairobi, Kenya.

Magwede K, Tshisikhawe MP, Luseba D, Bhat RB. 2014. Ethnobotanical survey of medicinal plants used in treatment of ticks. Intl J Exp Bot 83: 155-165. DOI: 10.32604/phyton.2014.83.155.

Mariita RM, Ogol CKPO, Oguge NO, Okemo PO. 2011. Methanol extract of three medicinal plants of Samburu in northern Kenya shows significant antimycobacterial, antibacterial, and antifungal properties. Res J Med Plant 5: 54-64. DOI: 10.3923/rjmp.2011.54.64.

Mekonnen N, Mekonnen E, Ameni G. 2012. Evaluation of berries of P.dodecandra for growth inhibition of Histoplasma capsulatum and treatment of cases of epizootic lymphangitis in Ethiopia. Asian Pac J Trop Biomed 2: 505-510. DOI: 10.1016/S2221-1691(12)60086-0.

Mesfin F, Seta T, Assefa A. 2014. An ethnobotanical study of medicinal plants in Amaro Woreda, Ethiopia. Ethnobot Res Appl 12: 341-354. DOI: $10.17348 /$ era.12.0.341-354.

Miegoue E, Tendonkeng F, Payne VK, Lemoufouet J, Kouam KM, Boukila B, Pamo TE. 2013. Acaricidal effect of foam soap containing essential oil of Ocimum gratissimum leaves on Rhipicephalus lunulatus in the western highland of Cameroon. Bull Anim Hlth Prod Afr 61: 535-541.

Mohammed AH, Khulood AS, Zawan HM, Afaf MW, Qasim AR. 2013. Study of total phenol, flavonoids contents and phytochemical screening of various leaves crude extracts of locally grown Thymus vulgaris. J Nat Prod 3: 705-710. DOI: 10.1016/S22211691(13)60142-2.

Musila MF, Dossaji SF, Nguta JM, Lukhoba CW, Munyao JM. 2013. In vivo antimalarial activity, toxicity and phytochemical screening of selected antimalarial plants. J Ethnopharmacol 146: 557-561. DOI 10.1016/j.jep.2013.01.023.

Namulindwa A, Nkwangu D, Oloro J. 2015. Determination of the abortifacient activity of the aqueous extract of Phytolacca dodecandra leaf in Wistar rats. Afr J Pharm Pharmacol 9: 43-47. DOI: 10.5897/AJPP2014.4227.

Nguta J, Mbaria J, Mvula W. 2013. Brine shrimp toxicity and in vitro antimicrobial activity of Piliostigma thonningii from Kenya and Malawi against some pathogens of human and veterinary importance. J Vet Med Anim Health 5:251-256.

Odhiambo J, Dossaji S, Lukhoba C, Yenesew A. 2014. Antifungal activity, brine shrimp cytotoxicity, and phytochemical screening of Gladiolus watsonoides Baker (Iridaceae). J Pharm Res 8: 1218-1222.

Orozco OL, Lentz DL. 2005. Poisonous Plants and their uses as insecticides in Cajamarca, Peru. Econ Bot 59:169-173. DOI: 10.1663/0013-0001(2005)059[0166:PPATUA]2.0.CO;2.

Parveen S, Godara R, Katoch R, Yadar A, Verma PK, Katoch M, Sign NK. 2014. In vitro evaluation of ethanolic extract of Ageratum conyzoides and Artemisia absinthium against cattle tick, Rhipicephalus microplus. Sci World J14: 6-14. DOI: 10.1155/2014/858973

Rajput ZI, Hu S, Chen W, Arijo A, Axiao C. 2006. Importance of ticks and their chemical and immunological control in livestock. J Zhejiang Univ Sci B 7: 912-921. DOI: 10.1631/jzus.2006.B0912.

Rey D, Pautou M, Meyran JC. 1999. Histopathological effects of tannic acid on the midgut epithelium of some aquatic Diptera larvae. J Invertebr Pathol 73: 173-181. DOI: 62110.1006/jipa.1998.4810.

Rosenkranz V, Wink M. 2007. Induction of apoptosis by alkaloids, nonprotein amino acids, and cardiac glycosides in human promyelotic HL-60 cells. Z Naturforsch C J Biosci 62: 458-466. DOI: 10.1515/znc-2007-5-621.

Ruskin S, Kumari V, Gopukumar T, Praseetha K. 2014. Evaluation of phytochemical, antibacterial, and anti-cancerous activity of Cissus quadrangularis from south-western Ghats regions of India. Intl J Pharm Sci Rev Res 3: 12- 15.

Salwa HM. 2010. Ethno-veterinary and medicinal knowledge of crude plant extract and its method of application (traditional and modern) for tick control. World Appl Sci J 11: 1047-1054.

Sanjay G, Tiku AK. 2009. Botanicals in pest management: Current status and future perspectives. Intl J Biomed Life Sci 3: 317-320. DOI: 10.1007/978-1-4020-8992-3_12.

Sirama V, Kokwaro J, Owuor B, Yusuf A, Kodhiambo M. 2015. In-vitro anthelmintic activity of Vernonia amygdalina (Asteraceae) roots using adult Haemonchus contortus worms. Intl J Pharmacol Res 5: 17 .

Walker JB, Keirans JE, Horak IG. 2002. The Genus Rhipicephalus (Acari. Ixodidae): A Guide to Brown Ticks of the World. Cambridge University Press, London, U.K.

Wanzala W, Takken W, Mukabana W, Pala A, Hassanali A. 2012. Ethnoknowledge of Bukusu community on livestock tick prevention and control in Bungoma district, Western Kenya. J Ethnopharmacol 140: 298-324. DOI: 10.1016/j.jep.2012.01.021. 